\title{
小形誘導電動機の電磁振動について
}

\author{
正員石橋 文徳 (東芝) \\ 正員野田伸一（東芝) \\ 正員森 貞明 (東芝)
}

\section{Electromagnetic Vibration of Small Squirrel Cage \\ Three-Phase Induction Motor}

Fuminori Ishibashi, Member, Shinich Noda, Member, Sadaaki Mori, Member (Toshiba Conporation)

The small squirrel cage three-phase induction motor has been used in all types of industry for a number of years. Motor radial vibration and noise caused by electromagnetic force are addressed in this paper.

At first, the frequency of the harmonic fluxes, which are main factor of vibration and noise, is discussed. Then modes and frequencies of electromagnetic radial force wave, induced by these harmonic fluxes, were calculated.

Natural frequency responses and modes of experimental motors were measured. Also frequencies and modes of vibration were measured on a running experimental motor. The experimental data was compared with the calculated values.

As a result, it was newly confirmed that modes of the running motor were determined to be a function of the natural frequency mode of the structure, not by modes of the electromagnetic radial force wave. It became clear that these modes did not rotate around the core. They were stationary waves.

キーワード: 誘導電動機, 電磁振動, 電磁力波, 振動モード

\section{1.まえがき}

産業用として広範に使用されている小形かで形三相 誘導電動機( 以下, 誘導機と略記)の電磁振動と騒音の 発生のメカニスムについて检討した。

誘導機の騒音や高調波磁東についてはよく研究され ており，多数の論文も発表されている(1)-(5)。しかし， 電磁力波の周波数，モードや力，電磁力波による変位 や構造系の振動モードとの関係にういて定量的に㭘討 した論文は少ない。

ここでは，まず電磁振動や駩音の原因となる高調波 磁束の周波数について述へ，次にこれらの高周波磁束 による電磁力波の周波数，モードとその力を計算し た。機械系については誘導機停止時の搼造系の周波数
応答とモードを測定した。最後に誘䢙機の運転中の振 動の周波数とモードを測定してこれらの解析結果と比 較娭討した。

その結果, 誘䢙機の運転中の振動モードは電磁力波 によるモードでなく，構造采の固有モードに依存する ことが新しく明らかになった。またこのモードは定 在波であり，回転しないことも示された。

従来, 電磁力波と振動騒音の関係が明確でなった が，今回，誘導機運転中の鉄心の振動の形態を初めて 測定することができ，理論的に解析された電磁力波お よび振動騒音と測定された振動騒音の関係が明確にな つた。

これらの結果は, 誘導機の振動騒音の低減に有効て あると考えられる。 


\section{2. 軋磁力波による振動の計算}

〈2・1〉周波数とモード 一般に誘導機のギャッ プに(1)式の $n$ 次と (2)式の $m$ 次の高調波磁束が存 在している場合,

$$
\begin{aligned}
& b_{n}=B_{n} \sin \left(\omega_{n} t-n \frac{1}{P / 2} \frac{\pi}{\tau} x_{1}\right) \\
& b_{m}=B_{m} \sin \left(\omega_{m} t-m \frac{1}{P / 2} \frac{\pi}{\tau} x_{1}\right)
\end{aligned}
$$

これらの2 個の高調波磁束による半径方向の電磁力波 は, 次の(3)式の上うになる。

$$
\begin{aligned}
f_{r}= & (\text { 定数 }) \times B_{n} \cdot B_{m}\left\{\cos \left(\omega_{n}-\omega_{m}\right) t\right. \\
& \left.-(n-m) \frac{1}{P / 2} \cdot \frac{\pi}{\tau} x_{1}\right\} \\
& -\cos \left\{\left(\omega_{n}+\omega_{m}\right) t-(n+m) \frac{1}{P / 2} \cdot \frac{\pi}{\tau} x_{1}\right\}
\end{aligned}
$$

ここで, $f_{r}$ : 電磁力波, $b_{n}, b_{m}: n$ 次, $m$ 次 の高調波磁束密度, $B_{n}, B_{m}: b_{n}, b_{m}$ の最大 萑, $\omega_{n}, \omega_{m}: b_{n}, b_{m}$ の角速度， $n, m$ : 高部波 次数, $P:$ 極数, $\tau:$ 極ピッチ, $x_{1}:$ 固定子 側座栖

表 1 電磁力波のモードと周波数

Table 1. Modes and frequencies of elec. tromagnetic radial force waves.

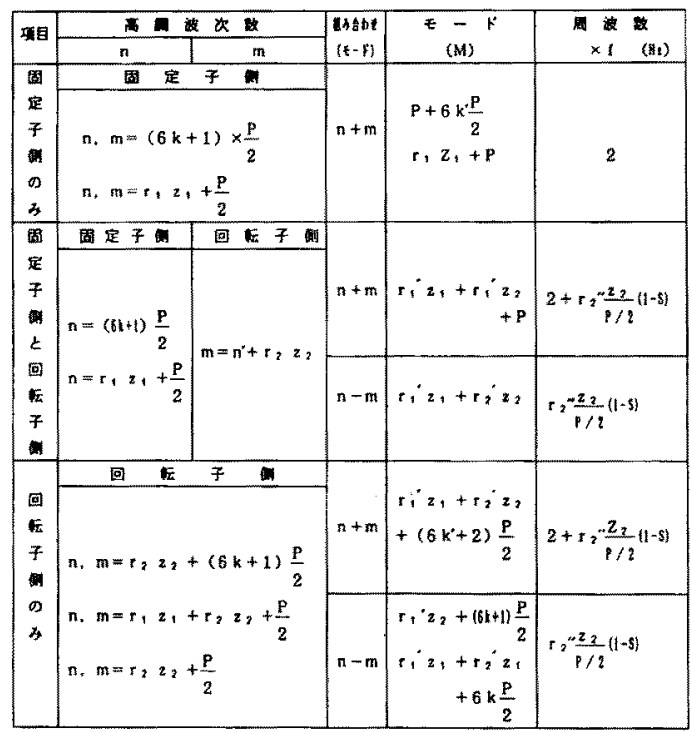

記譬ゆ説明

$n, n^{*}, m$ ：高賙波次数， $z_{1}, z_{2}$ ：固定子と回枟子スロット数 $P:$ 極数。 $S:$ 滑 $\eta, r_{1}, r_{1}^{\prime}, r_{2}, r_{2}^{\prime}, r_{2}^{\prime \prime}, k: 0$ 合也整数
誘導機では文献（1）に示されるように多数の高諝波 磁束が発生しており，その組合せは膨大になる。ここ ては主磁束やスロット高調波磁束などの磁束密度が比 較的大きな周波数の組合せについて検討すると次のよ うになる。

（i）固定子高調波磁束（含基本波磁束）どうしの組 合世

（ii）固定子高調波磁束と回転子高調波磁束の組合 せ

（iii）回転子高調波磁束どうしの組合せ

これをモードと周波数に分類して示すと表 1 のよう になる。

〈2・2〉軋磁力と变位誘導機のギャップの高調 波磁束により発生する電磁力波は，種々のモードを有 する。一般に，誘導機の鉄心は電磁力波の作用によ り,電磁力波のモードに沿って変形，振動すると考え られている。作用する電磁力の計算式は，電磁力波の モードによって異なり，次のような数式により計算さ れる(2)。

（1）モード0の場合 固定子高調波磁束と回転 子高調波磁束により生ずる場合が一般的で, ギャッブ 面単位周長あたりの電磁力は次式となる。

$$
F_{r}=4.06 \times l_{e} \times B_{n} \times B_{m} \quad(\mathrm{~kg} \mathrm{f} / \mathrm{cm})
$$

ここで， $F_{r}$ : 電磁力， $l_{e}$ : 鉄心の実奻長 $(\mathrm{cm}), B_{n}, B_{m}: キ ゙ ャ ッ フ ゚ の$ 高調波磁束密度 の最大値 $\left(\mathrm{Wb} / \mathrm{m}^{2}\right)$

（2）モード1の場合 モード1の場合はアンバ ランスカであり，主として回転子に作用する。電磁力 はギャップ面全周として計算される。

$$
F_{r}=4.06 \times \frac{\pi}{2} \times D \times l_{e} \times B_{n} \times B_{m} \quad(\mathrm{kgf})
$$

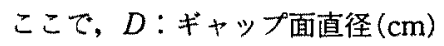

（3）モード2の場合 モード 2 の場合は電磁力 はモード1極あたり次式のようになる。

$$
\begin{aligned}
F_{r}= & 4.06 \times l_{e} \times D \times B_{n} \times B_{m} \\
& \times \frac{1}{2}\left\{\frac{1}{M-1} \sin \left(\frac{M-1}{M} \frac{\pi}{2}\right)\right. \\
& \left.+\frac{1}{M+1} \sin \left(\frac{M+1}{M} \frac{\pi}{2}\right)\right\} \quad(\mathrm{kg} \mathrm{f})
\end{aligned}
$$

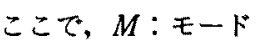

(4) モードが3以上の場合 モード3以上の煬 合はモード 1 極あたりの央磁力は次式となる。 


$$
F_{r}=4.06 \times \frac{1}{M} D \times l_{e} \times B_{m} \times B_{n} \quad(\mathrm{kgf})
$$

以上から振動や騒音の加振源である電磁力が求まっ た。この電磁力により振動し, 変形する鉄心の振幅, 変位量が次式のようにして計算される(2)。

(i) モード 2 の場合

$$
d=F_{r} / l_{e} \times D_{m}{ }^{3} /\left(6 \times E \times h_{c}{ }^{3}\right) \quad(\mathrm{cm}) \quad \cdots(8)
$$

(ii) モード 3 の場合

$$
d=F_{r} / l_{e} \times 9 \times D_{m}^{3} /\left(256 \times E \times h_{c}^{3}\right) \quad(\mathrm{cm})
$$

（iii） モード 4 の場合

$$
d=F_{r} / l_{e} \times D_{m}{ }^{3} /\left(75 \times E \times h_{c}{ }^{3}\right) \quad(\mathrm{cm}) \cdots(10)
$$

(iv）モード 5 以上の場合

$$
d=0.75 \times F_{r} / l_{e} \times D_{m}{ }^{3} /\left(M^{3} \times E \times h_{c}{ }^{3}\right) \quad(\mathrm{cm})
$$

ここで, $d:$ 変位 $(\mathrm{cm}), E:$ ヤング率 $2.1 \times$ $10^{6} \mathrm{~kg} / \mathrm{cm}^{2}, D_{m}$ : 固定子ヨーク部平均直径 $(\mathrm{cm}), h_{c}$ : 固定子鉄心 $コ ー ク$ 厚 $(\mathrm{cm})$

表 2 供試電動機の仕様

Table 2. Specification of tested motor.

\begin{tabular}{c|c}
\hline 項 目 & 内 容 \\
\hline 形 式 & 全閉外扇形 \\
相 数 極 & 三相 -4 極 \\
定 格 出 力 & $2.2 \mathrm{~kW}$ \\
電坘一周波数 & $200 \mathrm{~V}-60 \mathrm{~Hz}$ \\
電 流 & $8.8 \mathrm{~A}$ \\
スロット数 & \\
固定子/回転子 & $36 / 44$ \\
\hline
\end{tabular}

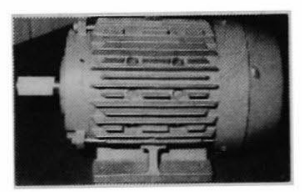

(a) 外観

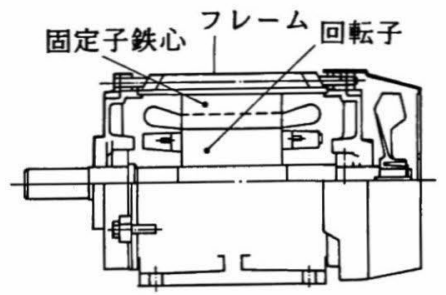

(b) 断面図

図 1 供試誘導機

Fig. 1. Tested motor.

\section{3. 実験方法}

誘導機運転中の振動の周波数とそのモードは表 2 に 示す全閉外扇形の三相 4 極 $2.2 \mathrm{~kW}$ のかご形誘導電動 機で測定した。供試電動機の外観および断面図をそれ ぞれ図 1 に示す。供試電動機は鋳物製のフレーム内に 固定子鉄心が圧入されており,この固定子鉄心の振動 モードを調查するためにフレームには等配に 12 䇢所 穴が開けてある。

運転時の振動モードの測定は商用電源無負荷にて実 施した。このモードの測定は図 2 に示すように 2 個の 振動ピックアップを用い, 1 個は固定基準検出点と し, 他方の測定位置を順次変えて得られた 2 点間の振 動情報から同一周波数における振動値と位相角を得 た。

固有振動モードはインパルス法による実験モーダル 解析を行った。測定点は図 3 に示すようにフレーム 25 箇所, 固定子鉄心 13 箇所の計 38 箅所とした。

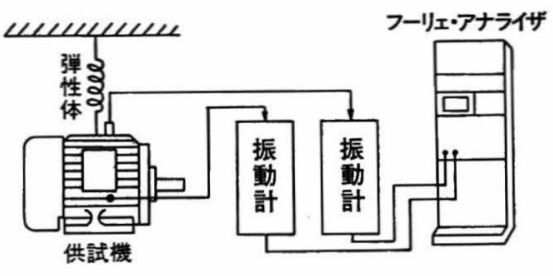

図 2 実験方法(運転時のモード)

Fig. 2. Experimental method (measured on running).

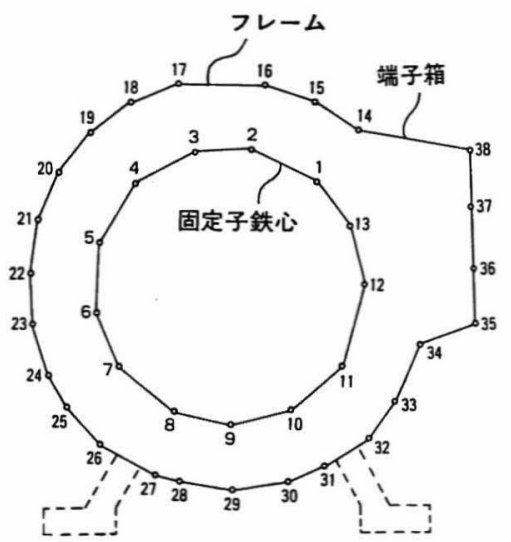

図 3 測定位置

Fig. 3. Measured points. 


\section{4. 誘逆機の振動形態}

〈4・1〉停止時の提功形態 誘導機の停止時, 寸 なわち電源を接続していない場合の誘茅機全体の固有 振動数と振動モードを調查するために打擊ハンマによ る打擊応答を測定し, 図 4 に示すような周波数応答グ ラフを得た。

またこの共振ピークの周波数について振動モードを 測定した結果を図 5 に示す。

これらの測定結果より，625 Hz は，回転子軸の曲 げ振動が誘導機全体を振動させるパラレルモードであ る。

$1,525 \mathrm{~Hz}$ と $2,052 \mathrm{~Hz}$ は固定子ラジアル曲げ振動し

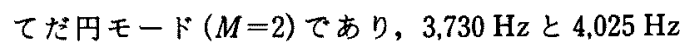

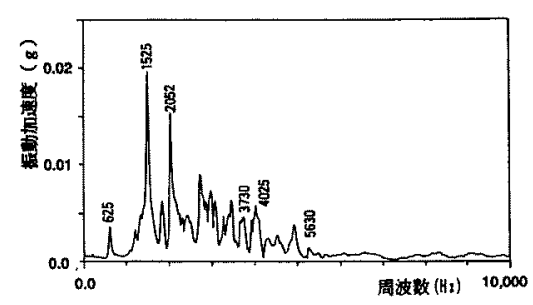

図 4 固有振動応答スペクトル

Fig. 4. Natural frequency spectrum.
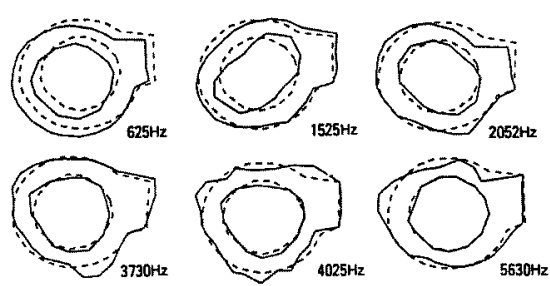

図 5 固有振動モード

Fig. 5. Natural vibration modes.

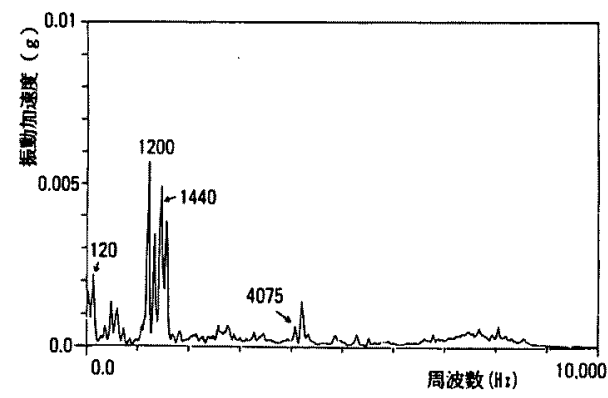

図 6 振動加速度スペクトル

Fig. 6. Vibration acceleration spectrum.
は三角形モード $(M=3), 5,630 \mathrm{~Hz}$ は四角形モート $(M=4)$ をもつことが判明した。

〈4・2〉運転中の振㲜形態誘導機を商用電源 $(60 \mathrm{~Hz})$ で運転中の誘導機鉄心の振動の周波数と振動 モードを2 個のピックアップとフーリエ・アナライザ を使用して測定した。

運転中の振動加速度を周波数分析した結果を図 6 に 示す。この中で振動值の大きな周波数について，運転 中の振動モードを測定した。時間的変化を $\theta$ で表し た運転中の振動モードを図 7 に示す。これらの結果よ り，1,200 Hz と $1,440 \mathrm{~Hz}$ は，だ円モード $(M=2) て ~$ あり， $4,075 \mathrm{~Hz}$ は三角形モード $(M=3)$ で挙動してい ることが明らかになった。またこれらの振動モード の腹と節は，移動するものではないことが明らかにな つた。すなかち，振動モードは回転せず，固定するも のであることが判明した。

\section{5. 考察}

電磁力波による電磁振動の計算と, 測定結果による

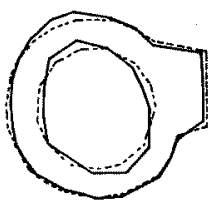

$\theta=0^{\circ}$

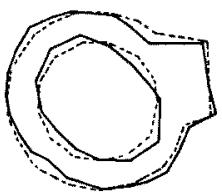

$\theta=0^{\circ}$

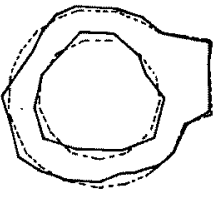

$\theta=0^{\circ}$

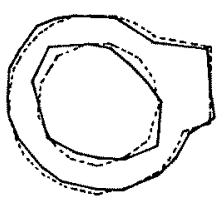

$\theta=90^{\circ}$

(a) $1,200 \mathrm{~Hz}(M=2)$

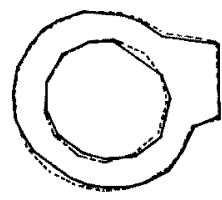

$\theta=90^{\circ}$

(b) $1.440 \mathrm{~Hz}(M=2)$

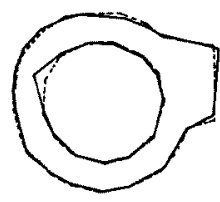

$\theta=90^{\circ}$

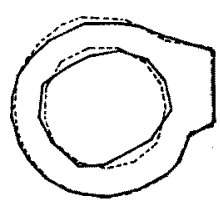

$\theta=180^{\circ}$

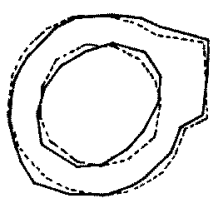

$\theta=180^{\circ}$

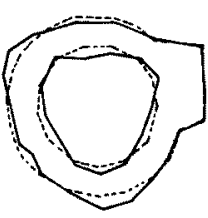

$\theta=180^{\circ}$

(c) $4,075 \mathrm{~Hz}(M=3)$ $200 \mathrm{~V}-60 \mathrm{~Hz}$ 無刍荷 実線：変形(運檕時) 破線：变形前(停止時)

図 7 運転中の振動モード

Fig. 7. Vibration modes on running. 
振娌周波数とモードおよび振幅について比较㛟討して みる。

\section{〈5.1〉振功周波数とモードについて}

(1) $1,200 \mathrm{~Hz}$ の場合 固定子側の 19 次の漊高 調波束と回転子側の 21 次渾の高調波磁束によって 発生するものである。

高和波磁束の次数，モードと周波数は表 1 上り次の ように計算される。

$$
\begin{aligned}
& n=\frac{1 \times 36}{4 / 2}+1=19, m=\frac{-44 \times 1}{4 / 2}+1=-21 \\
& \text { モードは } \\
& |n+m|=\left|(19-21) \times \frac{4}{2}\right|=4
\end{aligned}
$$

また周波数は，

$$
\left\{2-1 \times \frac{44}{4 / 2}(1-0)\right\} \times 60=1,200 \mathrm{~Hz}
$$

1,200 Hz はモード 4 となるが, 運転中の振動は図 7に示すようにモード2 となっている。

一方, 鉄心の振動系は $1.525 \mathrm{~Hz}$ に固有振動数があ る。 $1,200 \mathrm{~Hz}$ は $1,525 \mathrm{~Hz}$ の共振鋫囲であり, そのと きのモード 2 となっているため, 電磁力波としてはモ 一ド 4 で発生するが構造系の振動形態に変形したもの と推定される。

（2） $1,440 \mathrm{~Hz}$ の場合 固定子側の 17 次の漊高 調波磁束と回転子側の 23 次の渾高調波磁束によって 発生するものである。高調波磁束の次数，モードと周 波数は表 1上り次のように計算される。

$$
\begin{aligned}
& n=\frac{-1 \times 36}{4 / 2}+1=-17, m=\frac{44}{4 / 2}+1=23 \\
& \text { モードは } \\
& |n+m|=\left|(-17+23) \times \frac{4}{2}\right|=12
\end{aligned}
$$

また周波数は，

$$
\left\{2+1 \times \frac{44}{2}(1-0)\right\} \times 60=1,440 \mathrm{~Hz}
$$

1,440 Hz はモード 12 となるが,一般にこのような 大きなモードの振動は構造系としては発生しにくい。

運転中の振動のモードは図 7 に示すように 2 となっ ている。電磁力波としてはモード 12 で発生するが， 鉄心の固有㩒動数の関保から構造系の振動形態モード 2 に変形したものと推定される。

(3) $4,075 \mathrm{~Hz}$ の場合 固定子側の 71 次の耐高 調波磁束と回転子側の 67 次の溝高調波磁束によって 発生するものである。高調波磁束の次数，モードと周 波数は表 1 上り次の上うに計算される。

$$
n=\frac{-4 \times 36}{4 / 2}+1=-71, m=\frac{-3 \times 44}{4 / 2}+1=67
$$

学部D, 112 巻 3 号, 平成 4 年

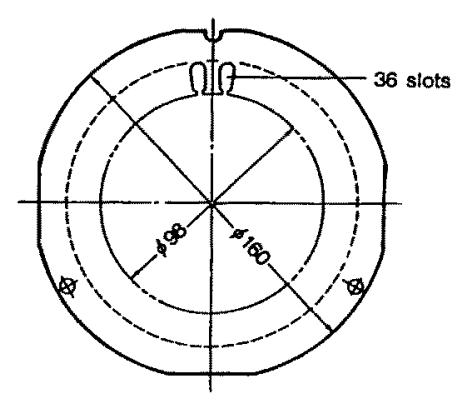

図 8 固定子鉄心断面

Fig. 8. Section of stator core.

モードは

$$
|n+m|=\left|(-71+67) \times \frac{4}{2}\right|=8
$$

また周波数は、

$$
\left\{2+3 \times \frac{44}{4 / 2}(1-0)\right\} \times 60=4,080 \mathrm{~Hz}
$$

$4,075 \mathrm{~Hz}$ で測定された運転中の振動モードは図 7 に示すように3である。図4に示す鉄心の振動の固有 振動が 4,025 Hzにあり，かつ振動モードが 3 になつ ているため, 電磁力波のモードが構造系のモードに変 化したものと考えられる。

以上の 3 個の振動周波数の場合がわかるように、い ずれも誘導機の運転中の振動モードは, 電磁力波の力 波のモードとは異なり，構造系の固有振動モードに追 従した挙動となっている。

これは電磁力波モードである強制振動が電磁力波の モードで作用しても，構造系の固有振動モードにより 振動することを示している。すなわち，電磁力波の加 振力の周波数が構造系の固有振動数近傍にある場合 は, 構造系の固有振動モードに電磁力波の加振力が同 調して構造系の固有振動モードとして振動する。従つ て, 電磁力波による加振力は構造系の固有振動モード で振動することになる。

また構造系の固有振動モードは，図８に示すように 固定子鉄心の外周の一部カットや穴などによる非対称 構造のため，固定したモードになっている(6)。

〈5.2〉振动振幅の比较第 2 章の計算式により 振動の振幅は計算できるが，構造系の固有振動数によ る影響を考慮する必要がある。構造系の固有振動数を 考慮する場合，固有振動数近傍における振幅の増大は 振幅倍率として次式で与えられる(7)。

$$
\frac{X}{X_{0}}=\frac{1}{\sqrt{\left\{1-\left(\frac{\omega}{\omega_{0}}\right)^{2}\right\}^{2}+\left(2 \zeta \frac{\omega}{\omega_{0}}\right)^{2}}}
$$


表 3 振動振幅の比較

Table 3. Comparison of vibration amplitude.

\begin{tabular}{|c|c|c|c|}
\hline 項 目 & 濑 & 健 & 部算值 \\
\hline 周诐数 $(\mathrm{Hz})$ & 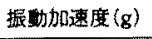 & 片振幅 (mm) & 片振幅 (mm) \\
\hline 120 & $3.008 \times 10^{-3}$ & $7.333 \times 10^{-5}$ & $1.436 \times 10^{-4}$ \\
\hline 1.200 & $3.80 \times 10^{-3}$ & $9.264 \times 10^{-7}$ & $3.276 \times 10^{-6}$ \\
\hline 1.326 & $4.221 \times 10^{-5}$ & $8.528 \times 10^{-7}$ & $1.629 \times 10^{-6}$ \\
\hline 1.440 & $4.707 \times 10^{-3}$ & $7.969 \times 10^{-7}$ & $9.607 \times 10^{-8}$ \\
\hline 4,075 & $4.592 \times 10^{-4}$ & $9.708 \times 10^{-8}$ & $3.567 \times 10^{-3}$ \\
\hline
\end{tabular}

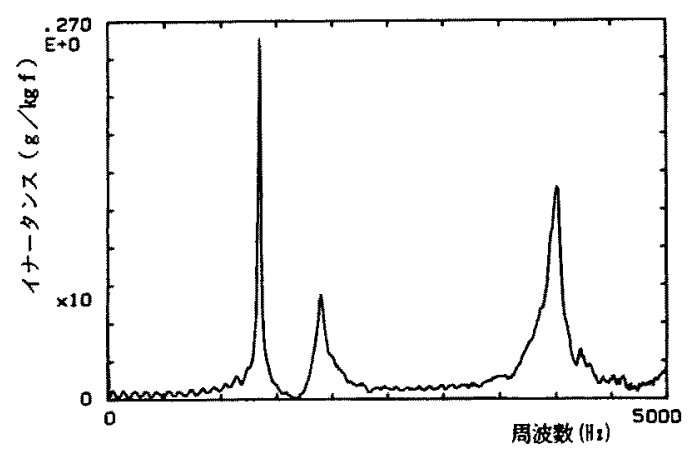

(a) 鉄心単体

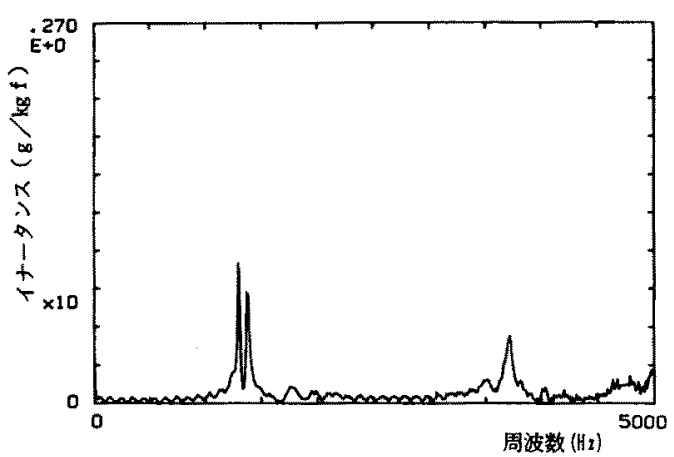

(b) フレームスり鏠心

図 9 打撃応答

Fig. 9. Impulse response.

ここで, $X$ : 振動振幅, $X_{0}$ : 固有振動数に おける振動振幅， $\omega$ : 振動数， $\omega_{0}$ : 固有振動 数, $\zeta:$ 隇衰比率 $(0.02)$

第 2 章の計算式と(12)式により電磁力波の計算によ るモードを使用して計算し，汼定值と比較すると表 3 のようになる。

ほとんど計算値のほうが，測定值より大きくなって いる。この要因は次のように考えられる。
計算の場合は鉄心単体で計算を行った。一方，減定 した誘導機の場合は鉄心が錆物製フレームに圧入され ている。従って誘導機の場合，鉄心は外側からフレー ムで拘束された状態にあるために鉄心の振幅か鋳物繁 フレームの減衰効果により抑制されたためであると考 えられる。

鋳物フレーム入り鉄心と鉄心単体について打摮を与 えたときの振動応答を図 9 に示すが，錶物フレームを 入れた減衰効果が認められる。

以上, $2.2 \mathrm{~kW}$ について検討したが, $4 \mathrm{P}-3.7 \mathrm{~kW}$ の事例(8) からもわかるように固定子の固有振動数の 領域に電磁力波が作用する場合, 振動モードは構造系 の固有振動モードになる。また，この振動モードは回 転せず，固定するものであることが判明した。

また，これらのことは小形の誘導電動機において共 通のものであり，一般の小形三相誘導電動機に適用て きる。

\section{6.むすひ}

運転中の誘㛵機の振動の状態を測定し，電磁力波の 理論により導出される振動の状態と比較した結果, 次 のようなことが明らかになった。

（1）運転中の振動のモードは電磁力波のモードと は異なり，共振系の範囲の場合は鉄心すすなわち構造 系の固有振動モードに依存する。

（2）鉄心，すなわち構造系の振動モードは定在波 であり回転しない。鉄心の特定の場所が常に振動の璂 や節になる。

（3）鉄心の振幅についても定量的な解析の方法が 明らかになった。

本論文で明らかになった結果は，小形三相誘導電動 譏の振動臨音の低隇や予測に役立古，低騒音電動機の 研究開発に有用である。

最後に，本論文は産業沁用部門全国大会で講演発表 した俩演論文 ${ }^{(9)}$ に加筆修正したものであることを付 記し，貴重な御討論をいただいた各位にお礼申し上げ ます。また，研究を行うにあたって種々の御指導をい ただいた当社重電技術研究所関係各位に対し深く謝意 を表します。

(平成 3 年 8 月 26 日受付)

\section{文献}

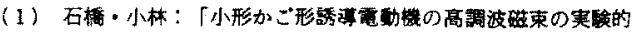
芳察了, 学解 D, 110,891 (平 2-8)

(2) M. Liwschutz-Garik \& C.C. Whipple ; Alternating Current Machines (1961) D. Van. Nostrand Co. Ltd.

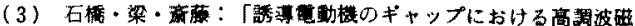

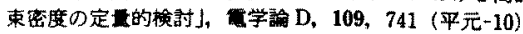

(4) P-G, Sperling: "Erfahrungen bei der Vorausberechnung 
elektromagnetisch erzeugter Maschinengerausche", Siemens-Zeitschrift, 43, 894 (1969)

(5) F. Kako, et al. : "Experimental study on magnetic noise of large induction motors", IEEE Trans. Power Apparatus Syst., PAS-102, 2805 (1983)

(6) S. Noda, et al. : "Effect of coils on natural frequencie of stator cores in small induction motors", IEEE Trans. Energy Conversion, EC-2, 93 (1987)

（7）小堀：実用振動計算法, p. 62 (昭 56) 工学図書

（8）森・野田・鈴木：「誘導電動機の電磁振動モードの一考察」, 昭 63 電気学会全大, No. 609

（9）石橋・野田・森：「小形かご形誘達電動機の電磁振動の一考 察了, 平 2 電気学会産業応用部門全大, No. 23

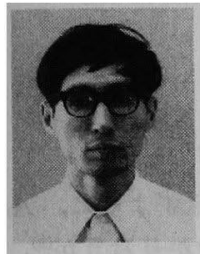

\section{石 橋 文 徳 (正員)}

昭和 42 年 3 月京都大学工学部電気工 学科第 2 学科卒業。同年 4 月(株) 東芝入 社。同社三重工場回転機部門および重電 技術研究所にて誘導電動機, 特殊可変速 電動機やパワーエレクトロニクス関係の研究・開発に従事。 IEEE 会員。

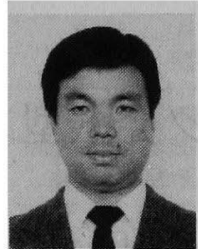

野 田 伸 - (正員)

昭和 57 年 3 月芝浦工業大学機械工学 科卒業。 49 年 4 月 (株) 東芝入社。 51 年 東芝京浜事業所重電技術研究所にて電気 機械の振動解析に従事。58 年より東芝 三重工場重電技術研究所にて同分野および構造解析従事。 日本機械学会会員。

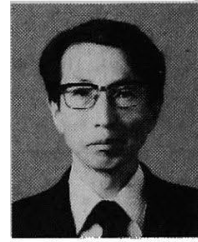

\section{森 貞 明（正員）}

昭和 38 年 3 月三重県立四日市工業高 校機械科卒業。同年 4 月 (株)東芝入社。 中・小形誘導電動機の機械現象の研究お よび機械要素技術開発に従事。現在，同 社重電技術研究所主査。日本機械学会会員。 